\title{
PENERAPAN BELAJAR YOGA SEBAGAI PENINGKATAN KECERDASAN EMOSI GURU DAN MURID
}

\author{
Oleh : \\ ${ }^{1}$ Ida Ayu Komang Werdi Purniasih, ${ }^{2}$ I Wayan Suyanta \\ werdi.purniasih@yahoo.com \\ suyanta.kaler@gmail.com \\ Kepala TK Madhu Vidya \\ Dosen IHDN Denpasar
}

\begin{abstract}
Abstrak
Penelitian ini memfokuskan kajian pada penerapan pembelajaran yoga yang dilaksanakan oleh para guru dan siswa. Keseharian dilakukan dengan meditasi dan yoga asana sebelum memulai pembelajaran. Kajian pustaka terkait dengan kecerdasan emosional anak usia dini dan yoga sutra patanjali. Metode pada penelitian ini menggunakan analisis observasi, pre test dan post test. Melibatkan peserta didik dan guru dari TK Madhu Vidya yang berjumlah 57 anak dan 3 orang guru. Penelitian ini menunjukkan adanya (1) mengenal bentuk bentuk emosi diri sendiri, (2) meningkatkan kemampuan guru dan peserta didik dalam mengelola emosi dalam diri, (3) membina hubungan dan berkomunikasi dengan orang lain.

Kata Kunci: Anak Usia Dini, Kecerdasan Emosional, Yoga

This research focuses on the study of the application of yoga learning carried out by teachers and students. Their life is done by meditation and yoga asana before starting learning. The literature review is related to emotional intelligence of early childhood and Yoga Sutra Patanjali. The method in this study used observation analysis, pre test and post test. Involving students and teachers from Madhu Vidya Kindergarten, totaling 57 children and 3 teachers. This study shows that there is (1) recognizing the formof self-emotion, (2) increasing the ability of teachers and students in managing emotions in themselves, (3) building relationships and communicating with others.
\end{abstract}

Keywords: Early Childhood, Emotional Intelligence, Yoga 


\section{LATAR BELAKANG}

Anak Adalah anugrah tuhan yang sangat berharga. Anak yang lahir ke dunia membawa kecerdasan masing masing. Masa kanak kanak merupakan tahun tahun awal kehidupan yang sangat penting. Sejak seorang bayi lahir, sel sel otaknya berkembang secara luar biasa dengan membuat sambungan sambungan antar sel dan proses inilah yang membentuk pengalaman yang akan dibawa seumur hidupnya (Nugraha dan Rachmawati, 2011). Berbagai penelitian telah menunjukkan bahwa lebih dari lima puluh persen perkembangan individu terjadi pada masa usia dini.

Demikian hakikat usia dini, sehingga diitilahkan sebagai usia emas atau paling berharga (Nugraha dan Rachmawati, 2011). Perlakuan yang tidak baik yang dialami anak di usia sangat muda akan merusak diri anak, sebab pengalaman adalah arsitek dan semacam pola cetak bagi perkembangan selanjutnya. Pada awal masa kanak kanak emosi anak sangat kuat, biasanya tampak mencolok pada anak usia 2,5 sampai 3,5 tahun yang dikenal dengan usia degil (dimana emosi terpusat pada diri) dan usia 5,5 sampai 6,5 tahun (Hurlock, 1980). Pergolakan emosi yang terjadi pada AUD tidak lepas dari berbagai macam pengaruh, seperti lingkungan tempat tinggal, keluarga, sekolah maupun teman teman sebaya serta aktivitas- aktivitasnya sehari hari.

Pergolakan emosi terjadipada AUD terjadi karena tuntutan penyesuaian diri dari lingkungannya baik dari lingkungan keluarga, sekolah maupun teman bermain. Maka akibat dari tuntutan yang tidak terpenuhi, hal itu akan menimbulkan dampak negative bagi anak itu sendiri, seperti rasa takut berlebihan, terganggunya konsentrasi pada anak, timbulnya rasa tidak nyaman, kurangnya rasa percaya diri, dan emosi yang sangat tak terkendali.

Howes dan Herald (1999) menjelaskan kecerdasan emosi merupakan komponen yang membuat seseorang menjadi pintar menggunakan emosi. Kecerdasan emosi menyediakan pemahaman yang lebih mendalam dan lebih utuh tentang diri sendiri dan orang lain. Pendapat lain, Goleman (1999) mengemukakan bahwa kecerdasan emosi merupakan kemampuan yang dimiliki oleh seseorang untuk mengenali, menyadari dan mengelola emosi baik pada diri sendiri maupun orang lain untuk digunakan secara efektif, membangun hubungan yang produktifdan meraih keberhasilan, sehingga apabila seseorang pandai menyesuaikan diri dengan orang lain dan tidak mudah prasangka, orang tersebut akan memiliki emosionalitas yang baik dan akan lebih mudah menyesuaikan diri dalam pergaulan social serta lingkungannya. Berbagai penelitian juga menyimpulkan, perkembangan yang diperoleh pada masa usia dini sangat memengaruhi perkembangan anak pada tahap berikutnya dan meningkatkan produktivitas kerja di masa dewasanya. Pendidikan dini bukan hanya memiliki fungsi strategis, tetapi juga mendasar dan memiliki andil memberi dasar kepribadian anak dalam sikap, perilaku, daya cipta dan kreativitas, serta kecerdasan kepada calon-calon SDM masa depan.

Berbagai penelitian dalam bidang psikologi anak membuktikan anak-anak dengan kecerdasaan emosional yang tinggi adalah anakanak yang bahagia, percaya diri, populer, dan lebih sukses. Mereka lebih mampu menguasai gejolak emosinya, menjalin hubungan yang manis dengan orang lain, bisa mengatasi stres, dan memiliki kesehatan mental yang baik. 

Dengan demikian, terbukti kecerdasan emosional diperlukan untuk mengatasi berbagai masalah dalam hidup ini dan menjadi dasar menjadi manusia dewasa yang bertanggung jawab, penuh perhatian, dan cinta kasih serta produktif.

Kecerdasan emosi anak di usia dini dapat berkembang dengan baik jika mendapat lingkungan yang baik pula. Menurut Goelman (1999) bahwa kecerdasan intelektual menentukan sukses seseorang sebesar 20\% sedangkan kecerdasan emosi memberikan kontribusi $80 \%$,oleh karena itu pendidikan di taman kanak kanak harus lebih menonjolkan kemampuan dalam mengelola emosi dalam diri. Pembangunan kecerdasan emosional (EQ) dalam dunia pendidikan terutama di sekolahsekolah tentunya bukantanggung jawab masingmasing individu ataupun orang tuanya. Disini dengan hadirnya guru di taman kanak kanak dapat membantu anak di usia dini untuk melatih emosi sehingga mereka dapat mengembangkan dan meningkatkan kecerdasan emosi yang mereka bawa sejak lahir. Seorang guru pun harus mampu memilikiperan untuk membentuk karakter dan pribadi anak didiknya. Peserta didik yang memiliki kecerdasan emosional baik tentunya sangat berpengaruh dalam hubungan interpersonal diantara mereka. Hubungan interpersonal yang sudah terbangun akan sangat bermanfaat untuk menanamkan kerja sama antara siswa dalam mengatasi persoalan yang diberikan oleh guru.

Guru adalah seorang yang memberikan ilmu pengetahuan kepada peserta didik (Siti Aisyah, 2014). Dalam menjalankan tugasnya seorang guru memiliki tanggung jawab yang sangat berat untuk membina jiwa dan watak anak didik. Dalam mengajar, guru harus memiliki keterampilan seperti : keterampilan bertanya, keterampilan mengadakan variasi, keterampilan menjelaskan, dan keterampilan mengelola kelas. Selain dari ketrampilan tersebut, seorang guru juga harus memiliki keterampilan dalam mengelola emosi. Seorang guru harus bersikap sabar, agar anak dapat bersikap positif, percaya diri dan peka terhadap lingkungan sekitar . Guru yang memiliki kecerdasan dalam mengelola emosinya dapat memberikan lingkungan yang terbaik untuk peserta didik. Sehingga mereka dapat menerima ilmu dengan nyaman dan senang.

Salah satu langkah efektif yang dapat dilakukan untuk guru dan peserta didik untuk mengembangkan kecerdasan emosionalnya adalah dengan mengikuti yoga. Yoga adalah system kesehatan menyeluruh yang terbentuk dari kebudayaan India kuno sejak 3000 SM (Sindhu, 2013). Yoga merupakan system yang menyadarkan dan mengantarkan kita ke pengembangan diri kesehatan lahir bathin untuk mencapai kebahagiaan. Yoga dapat meningkatkan daya ingat, konsentrasi, menajamkan tingkat intelektual, menyeimbangkan emosi sehingga membuat hidup lebih tenang dan bahagia. Bahkan yoga dapat menurunkan stress, memberikan ketenangan dan menambah kepercayaan diri (Sindhu, 2013).

Dari fenomena ini peneliti beranggapan bahwa penelitian mengenai kecerdasan emosi ditinjau dari keikutsertaan dalam program yoga menarik dan perlu untuk dilakukan. Penelitian ini dimaksudkan untuk mengetahui peran yoga dalammeningkatkan dan pengelolaan emosiguru taman kanak kanak dan anak anak usia dini.

Sebagaimana diketahui, bahwa dalam era sekarang kecerdasan emosi sangat diperlukan dalam kehidupan mereka sehari hari. Kecerdasan emosi harus dibangun sejak kecil, 
dan harus terus dilatih. Pelatihan pengelolaan emosi dapat dimulaidalam pendidikan anak usia dini (PAUD). Hasil pengamatan situasi di TK Madhu Vidya bahwa terdapat hampir sebagian anak memiliki emosi negative berlebihan dan sangat perlu ditingkatkan. Sejalan dengan hal tersebut, juga ditemukan 3 orang guru di TK Madhu Vidya yang memiliki emosi negative seperti kurang percaya diri,dan cepat stress.

Sehingga berdasarkan pengamatan peneliti, sangat perlu dilakukan upaya peningkatan dalam pengelolaan kecerdasan emosi peserta didik maupun guru. Dengan melihat pengamatan peneliti bahwa praktis yoga dapat membantu mengembangkan dan meningkatan pengelolaan kecerdasan emosional peserta didik dan guru, sehingga suasana dan lingkungan belajar di TK terasa menyenangkan dan penuh kasih sayang serta dapat membuat anak anak merasa sangat nyaman.

\subsection{Identifikasi Dan Perumusan Masalah}

Adanya beberapa anak dari Taman Kanak Kanak Madhu Vidya Celuk yang memperlihatkan dampak negative dari ketidakstabilan emosi seperti kurangnya rasa percaya diri, rasa takut yang berlebihan, kurangnya rasa aman dengan lingkungan baru dan gangguan konsentrasi. Dimana dalam hal ini anak anak memilikikekkurangan dalam bergaul dan masalah tersebut memerlukan bantuan untuk menyesuaikan diri, dimana anak yang memiliki masalah tersebut terdiri dari dua puluh orang siswa.

Setelah dilakukan identifikasi berdasarkan observasi awal, permasalahan yang dapat dirumuskan adalah sebagaiberikut : Bagaimana penerapan Yoga terhadap Kecerdasan Emosional Pada Anak Anak Di Taman kanak Kanak Madhu Vidya Celuk?

\section{KAJIAN PUSTAKA}

\subsection{Kecerdasan Emosional}

Kita semua dilahirkan dengan bekal kecerdasan yang sangat luar biasa. Anak anak yang terlahir kedunia membawa kecerdasan masing masing. Salah satunya kecerdasan emosional. Kecerdasan emosional adalah kecerdasan untuk mengelola dan mengontrol emosi. Emosiadalah perasaan yang ada di dalam diri kita, dapat berupa perasaan senang atau tidak senang, perasaan baik atau buruk.

Menurut penelitian dari Daniel Goleman seorang psikolog dari Harvard University bahwa IQ akan dapat bekerja secara efektif apabila seseorang mampu memfungsikan EQ-nya. Hal ini dibuktikan dalam penelitian yang dilakukan di daerah kumuhpada kondisi kesulitan ekonomi dan ditemukan data hanya sekitar $20 \%$ saja masyarakat yang mempunyai IQ mampu bertahan hidup sedangkan sisanya berasal dari faktor lain termasuk kecerdasan emosi.

Emosi merupakan suatu keadaan yang kompleks, dapat berupa perasaan ataupun getaran jiwa yang ditandai oleh perubahan biologis yang munculmenyertai terjadinya suatu perilaku (Ali Nugraha dan Yeni Rachmawati, 2011). Secara konseptual kecerdasan emosion merupakan kemampuan untuk mengenali perasaan diri sendiri dan perasaan orang lain, kemampuan memotivasi diri sendiri, serta kemampuan mengelola emosi,dan perilaku social dengan baik pada diri sendiri dan dalam membina hubungan dengan orang lain (Agus Nggermanto,2001). Emosi dapat bersifat negative atau positive. Contoh emosi positive : cinta dan kebahagiaan. Sedangkan contoh emosi negative yang sering muncul pada masa kanak kanak yaitu rasa takut, tidak nyaman, iri hati, 
atau marah. Perasaan ini pun dapat dirasakan hingga besar seperti rasa tidak percaya diri, rasa takut, rasa marah dan depresi.

Fungsi dan Peranan Emosi untuk perkembangan anak adalah sebagai berikut. (1). Merupakan bentuk komunikasi sehingga anak dapat menyatakan segala kebutuhan dan mengekspresikan perasaannya pada orang lain. (2) Emosi berperan dalam mempengaruhi kepribadian dan penyesuaian diri anak dengan lingkungannya.

Beberapa tokoh mengemukakan tentang macam-macam emosi, antara lain Descrates. Menurut Descrates, emosi terbagi atas: Desire (hasrat), hate (benci), Sorrow (sedih/duka), Wonder (heran), Love (cinta) dan Joy (kegembiraan). Sedangkan JB Watson mengemukakan tiga macam emosi, yaitu : fear (ketakutan), Rage(kemarahan), Love (cinta). Sedangkan Goleamann melihat bahwa dalam emosi terdapat 8 macam: (a) Amarah: beringas, mengamuk, benci, jengkel, kesal hati (b) Kesedihan: pedih, sedih, muram, suram, melankolis, mengasihi diri, putus asa (c) Rasa takut: cemas, gugup, khawatir, was-was, perasaan takut sekali, waspada, tidak tenang, ngeri; (d) Kenikmatan: bahagia, gembira, riang, puas, riang, senang, terhibur, bangga; (e) Cinta: penerimaan, persahabatan, kepercayaan, kebaikan hati, rasa dekat, bakti, hormat, kemesraan, kasih; (f) Terkejut: terkesiap, terkejut;(g) Jengkel: hina,jijik, muak, mual, tidak suka; (h) Malu: malu hati, kesal

Kecerdasan Emosional(EQ) tumbuh seiring pertumbuhan seseorang sejak lahir hingga meninggal dunia. Pertumbuhan EQ dipengaruhi oleh lingkungan, keluarga, dan contoh-contoh yang didapat seseorang sejak lahir dari orang tuanya. Kecerdasan Emosi menyangkut banyak aspek penting, yang agaknya semakin sulit didapatkan pada manusia modern, yaitu: Empati (memahami orang lain secara mendalam), Mengungkapkan dan memahami perasaan , Mengendalikan amarah, Kemandirian, Kemampuan menyesuaikan diri, Disukai , Kemampuan memecahkan masalah antar pribadi, Ketekunan, Kesetiakawanan dan keramahan, sertaSikap hormat.

Emosi tersebut akan menghambat perkembangan seseorang jika tidak diasah secara tepat dan terus menerus. Maka dari itu sangat penting untuk mengembangkan kecerdasan emosional sejak dini. Perkembangan kecerdasan emosi anak anak dapat berjalan dengan maksimal jika guru sebagai pendamping dan pendidik di taman kanak kanak memiliki kecerdasan emosional yang baik pula.

\subsection{Yoga}

Yoga adalah system kesehatan menyeluruh yang terbentuk dari kebudayaan India kuno sejak 3000 SM (Sindhu, 2013). Yoga adalah ilmu holistic untuk pengembangan baik secara fisik, mentaldan spiritual. Yoga mencakup latihan fisik (asana) dan pikiran (meditasi). Yoga asana untuk melatih perkembangan fisik sehingga fisik berkembang dimulai secara maksimal dari sejak dini, dan untuk dewasa latihan yoga asana memiliki faedah untuk mempertahankan bentuk tubuh, mengontrol hormon di dalam tubuh. Meditasi juga dapat memberikan rasa percaya diri dan mengurangistress. Menurut Rachmawati (1998) bahwa proses relaksasi yang dilakukan pada anak, cukup efektif untuk pengenalan emosi diri mereka sendiri atau terbentuknya ketrampilan selfawareness.

Yoga asana merupakan latihan gerakan fisik yang menirukan seperti gerakan atau pose binatang atau benda sekitar kita, seperti pose 
ular cobra, pose busur, pose lilin, pose kelinci, pose pohon dan pose bunga lotus, dimana pose bunga lotus akan digunakan saat bermeditasi. Tahapan yoga asana ada 4 yaitu : (1) Pemanasan atau warming up bertujuan agar saat melakukan gerakan yoga asana otot kita tidak tegang; (2) Gerakan Yoga; (3) Massage bertujuan untuk melancarkan sirkulasi darah setelah melakukan yoga; (4) Relaksasi untuk memberikan energi baru untuk tubuh dan melatih pengenalan emosi diri. Biasanya relaksasi dilakukan dengan narasi atau musik instrumentalia. Sedangkan meditasi, kita lakukan dengan posisi duduk bersila tubuh tegak dan mata terpejam, pemusatan pikiran ada pada satu titik, dengan disertai pengaturan nafas. Meditasi juga bisa dilakukan dengan musik.

Yoga asana maupun meditasi yang dilakukan secara terus menerus dan sungguh sungguh akan memberikan faedah yang sangat luar biasa bagi tubuh dan pikiran kita maupun untuk anak anak. Beberapa manfaat latihan yoga bagi guru dan anak anak; (1) Melatih pengendalian diri; (2) Melatih mengelola emosi; (3) Melatih pemahaman terhadap apa yang mereka rasakan; (3) Menanggapi perasaan orang lain.

\section{METODE PENELITIAN}

Banyak aktivitas menggunakan strategi pelatihan (training). Tahapan tahapan aktivitas secara umum yaitu : penyemaian informasi (encoding), pengintegrasian informasi menjadi suatu pemahaman (decoding), perekaman informasi (storing), dan pembelajaran informasi (learning). Seluruh aktivitas tersebut dirancang bersama sama dan dilakukan dalam situasi informal dengan melakukan pelatihan dan pendampingan terhadap guru dan peserta didik di Taman Kanak Kanak Madhu Vidya.

\subsection{Observasi}

Observasi terhadap pelaksanaan kegiatan pelatihan mencakup ketekunan dan keseriusan guru dan peserta didik dalam mengikuti kegiatan pelatihan yoga. Instrument yang digunakan adalah lembar observasi. Penilaian dilakukan terhadap aspek aspek sikap dan aktivitas guru dan peserta didik yang mencirikan perilaku dan kemampuan guru dan peserta didik. Teknik pemberian skor pada masing masing indicator menggunakan skala dengan rentangan 1- 5.

\subsection{Pre -Test dan Post - Test}

Pre-test dilakukan di awal kegiatan untuk mengetahui pemahaman guru dan peserta didik tentang bagaimana mengelola kecerdasan emosi sebelum diberikan pelatihan yoga. Post-test dilaksanakan pada akhir pelatihan untuk mengetahui perubahan ketrampilan guru dan peserta didik dalam mengelola kecerdasan emosi setelah melakukan pelatihan yoga. Data pre-test dan post-test untuk guru dikumpulkan melalui tes yang akan mengungkapkan pemahaman guru tentang bagaimana cara mengelola kecerdasan emosi mereka. Sedangkan data pre test dan post test untuk peserta didik berbentuk laporan narasi setelah mengadakan tes menggunakan sebuah permainan.

\subsection{Teknik Analisis data dan Kriteria Keberhasilan Program}

Data dari hasilpre-test dan post-test tentang pemahaman guru dan peserta didik sehubungan dengan cara pengelolaan kecerdasan emosi dan data peserta dalam melakukan kegiatan yoga dianalisis dengan teknik statistic deskriptif. 


\subsection{Khalayak Sasaran strategis}

Secara umum, tujuan penelitian ini adalah untuk meningkatkan kemampuan pengelolaan kecerdasan emosi guru dan murid melalui praktis yoga. Sehubungan dengan hal tersebut, khalayak sasaran strategis dan tepat dilibatkan adalah guru dan peserta didik dari TK Madhu Vidya yang berjumlah 57 anak dan 3 orang guru.

Rendahnya kemampuan guru dan peserta didik dalam mengelola kecerdasan emosional menyebabkan mereka merasa kurang nyaman bahkan kurang percaya diri dan kurangnya pemahaman guru dalammengelola emosi untuk membantu anak anak mengembangkan kecerdasan emosimereka.

\subsection{Keterkaitan}

Kegiatan penelitian ini melibatkan Taman kanak kanak Madhu Vidya, Guru dan Peserta didik di TK Madhu Vidya, Celuk. Keuntungan yang diperoleh masing masing pihak sebagai berikut : (1) Taman Kanak Kanak Madhu Vidya sebagai wadah menimbailmu akan mendapatkan inspirasi pengembangan pengetahuan untuk pengembangan peserta didik maupun tenaga pendidik secara menyeluruh. (20 Guru sebagai pendidik dan teladan akan memperoleh banyak inspirasi dalam mengembangkandiridan mampu memberikan contoh dalam pengembangan pengelolaan emosi yang baik untuk peserta didik; (3) Murid sebagai generasi bangsa yang harus mendapatkan pengalaman dalam pengelolaan emosi sebagai bekal masa depan.

\section{HASIL PENELITIAN DAN PEMBAHASAN}

\subsection{Hasil}

Kegiatan Penelitian ini dilaksanakan dalam bentuk pelatihan dengan peserta guru dan peserta didik dari Taman Kanak Kanak Madhu Vidya Celuk. Pelatihan dilaksanakan di salah satu ruangan kelas TK Madhu Vidya Celuk. Pelatihan dilaksanakan secara berkesinambungan dimulai dari tanggal 22 Pebruari 2016 dan berakhir pada tanggal 18 Maret 2016. Kegiatan diawal dengan memberikan pre-test. Pre-test dilakukan diawal kegiatan untuk mengetahuipemahaman guru dan peserta didik dalam mengenal dan mengelola kecerdasan emosi di TK Madhu Vidya Celuk sebelum diberikan pelatihan yoga. Pre- test yang diberikan untuk guru dilaksanakan secara verbal dengan menanyakan kepada mereka pertanyaan berikut :

Hasil pre-test menunjukkan :

\begin{tabular}{|c|l|l|}
\hline No. & Pertanyaan & Hasil \\
\hline 1. & Menurut anda, apakah emosi itu? & $\begin{array}{l}\text { 85\% peserta mengatakan emosi adalah ungkapan } \\
\text { rasa marah atau sedih, 15\% peserta mengatakan } \\
\text { emosi adalah ungkapan perasaan sedih atau } \\
\text { bahagia }\end{array}$ \\
\hline 2. & $\begin{array}{l}\text { Apakah anda mampu mengenali } \\
\text { emosiyangtimbuldalamdirianda? }\end{array}$ & $\begin{array}{l}\text { 97\% dari 85\% yang mengatakan sering tidak } \\
\text { menyadari emosi yang timbul dari diri mereka }\end{array}$ \\
\hline 3. & $\begin{array}{l}\text { Apakah anda pernah merasakan } \\
\text { emosi negative seperti marah, } \\
\text { sedih atau kecewa? }\end{array}$ & $\begin{array}{l}100 \% \text { peserta mengatakan pernah merasakan } \\
\text { emosi negative seperti marah, sedih atau kecewa }\end{array}$ \\
\hline
\end{tabular}




\begin{tabular}{|c|l|l|}
\hline 4. & $\begin{array}{l}\text { Apakah emosi negative seperti } \\
\text { marah, sedih dan kecewa yang } \\
\text { timbul memberikan dampak } \\
\text { negative yang fatal seperti stress? }\end{array}$ & $\begin{array}{l}\text { 80\% peserta mengatakan emosi marah, } \\
\text { sedih atau kecewa dapat memberikan dampak } \\
\text { yang fatal seperti stres, 20\% peserta mengatakan } \\
\text { emosi negative tersebut dapat diredam tapi sangat } \\
\text { susah dan memerlukan waktu. }\end{array}$ \\
\hline 5. & $\begin{array}{l}\text { Apakah anda pernah belajar } \\
\text { yoga sebagai salah satu cara } \\
\text { mengelola emosi yang berdampak } \\
\text { negative tersebut? }\end{array}$ & $\begin{array}{l}\text { 95\% peserta belum pernah melakukan yoga } \\
\text { sebagai salah satu cara untuk mengelola emosi. } \\
5 \% \text { pernah mengikuti yoga namun sangat } \\
\text { jarang mempraktekkannya. }\end{array}$ \\
\hline
\end{tabular}

Dari hasil pre test yang diberikan hampir $85 \%$ peserta yaitu para guru menghadapi keadaan dimana emositidak dapat dikelola atau dikendalikan, ini akibat kurangnya kemampuan dalam mengenali emosi diri sendiri.

Pre-test yang diberikan untuk anak anak berupa permainan dimana peserta didik akan dibagi dalam tiga kelompok. Dari 57 anak dibagi menjadi 3 kelompok yang tiap kelompoknya terdiri dari 19 anak. Tiap kelompok kemudian berkumpul dan masuk ke dalam ruangan. Dari 19 anak dalam satu kelompok diberikan dua pilihan. Mereka boleh mengambilsatu permen enak lalu ke luar ruangan atau menunggu beberapa menit untuk mendapatkan dua permen. Dalam satu kelompok langsung terbagi dua, mereka yang ingin mendapatkan permen lalu menghabiskannya dan mereka yang bersedia menunggu beberapa saat lagi untuk mendapatkan tambahan 1 permen lagi.

Dari hasil pre-test menunjukkan bahwa hampir $90 \%$ anak anak memilih pilihan yang pertama yaitu mengambil satu permen lalu dengan segera menghabiskannya dan hanya $10 \%$ yang dapat bertahan menunggu untuk mendapatkan tambahan satu permen. Ini menunjukkan bahwa anak anak belum mampu mengendalikan emosinya. Mereka belum mampu menunda pemuasan keinginan, maka dari itu pelatihan ini sangat penting untuk mengembangkan kemampuan mereka dalam pengendalian emosi.

Kegiatan selanjutnya adalah pelaksanaan pelatihan dengan kegiatan yoga dengan menggunakan tahapan sebagai berikut :

Hasil pre-test menunjukkan :

\begin{tabular}{|c|l|l|}
\hline No. & Kelompok & Hasil \\
\hline 1. & Kelompok 1 & $\begin{array}{l}\text { Dari 19 anak, 15 anak memilihpilihan pertama yaitu } \\
\text { mengambilsatu permenlalu segera menghabiskannya }\end{array}$ \\
\hline 2. & Kelompok 2 & $\begin{array}{l}\text { Dari 19 anak, 12 anak memilihpilihan pertama yaitu } \\
\text { mengambilsatu permenlalu segera menghabiskannya }\end{array}$ \\
\hline 3. & Kelompok 3 & $\begin{array}{l}\text { Dari 19 anak, 13 anak memilihpilihan pertama yaitu } \\
\text { mengambilsatu permenlalu segera menghabiskannya }\end{array}$ \\
\hline
\end{tabular}




\begin{tabular}{|c|l|l|}
\hline \multirow{2}{*}{ FASE } & \multicolumn{2}{|c|}{ AKTIVITAS } \\
\cline { 2 - 4 } & PENDAMPING(trainer) & $\begin{array}{l}\text { PESERTA PELATIHAN } \\
\text { (guru dan peserta didik ) }\end{array}$ \\
\hline 1. Pemberian informasi & $\begin{array}{l}\text { Memberikan informasitentang } \\
\text { yoga Yoga asana dan meditasi }\end{array}$ & $\begin{array}{l}\text { Mendengarkan penjelasan } \\
\text { dengan seksama }\end{array}$ \\
\hline $\begin{array}{c}\text { 2.Praktekyoga, Relaksasi } \\
\text { dan meditasi }\end{array}$ & $\begin{array}{l}\text { Memberikan contoh gerakan } \\
\text { yogaMemberikan dan } \\
\text { membimbing peserta untuk } \\
\text { melakukan meditasi dan relaksasi }\end{array}$ & $\begin{array}{l}\text { Mempraktekkan contoh } \\
\text { gerakan yang diberikan dan } \\
\text { melakukan meditasi } \\
\text { bersama dan khusuk }\end{array}$ \\
\hline 3. Evaluasi & $\begin{array}{l}\text { Menanyakan tentang pengalaman } \\
\text { peserta didik saat melakukan yoga, } \\
\text { Melakukan test untuk mengetahui } \\
\text { apakah kecerdasan emosi dapat } \\
\text { meningkat. }\end{array}$ & $\begin{array}{l}\text { Mengemukakan pendapat } \\
\text { tentang apa yang dirasakan } \\
\text { saat mengikuti yoga } \\
\text { Mengikuti post test untuk } \\
\text { digunakan sebagai hasil } \\
\text { pengamatan. }\end{array}$ \\
\hline
\end{tabular}

Dalam melaksanakan kegiatan, dilakukan pula observasi. Observasi terhadap pelaksanaan kegiatan pelatihan mencakup ketekunan serta keseriusan guru dan peserta didik dalam mengikuti pelaksanaan pelatihan yoga. Instrument yang dipergunakan yaitu lembar observasi. Observasi adalah proses memperhatikan seorang anak dalam melakukan suatu kegiatan atau melakukan permainan, tanpa mencampurikegiatan anak tersebut (AliNugraha dan Yeni Rachmawati, 2011). Observasi juga dilakukan terhadap aktivitas guru saat mengikuti pelatihan. Penilaian dilakukan terhadap aspek aspek sikap dan aktivitas guru dan peserta didik selama mengikuti pelatihan yoga. Teknik pemberian skor pada masing masing indicator menggunakan skala lickert dengan rentang 1-5. Hasil Penilaian terhadap ketekunan dapat dilihat dari hasil di bawah ini :

\begin{tabular}{|c|l|c|c|}
\hline No. & Aspek yang diobservasi & \multicolumn{2}{|c|}{ Hasil penilaian } \\
\cline { 3 - 4 } & & Guru & Peserta didik \\
\hline 1. & Ketekunan mendengarkan informasi yang disampaikan & 5 & 3 \\
\hline 2. & $\begin{array}{l}\text { Keseriusan dalam melakukan gerakan dalam mengikuti } \\
\text { pelatihan yoga }\end{array}$ & 5 & 4 \\
\hline 3. & Keseriusan dalam melakukan meditasi & 5 & 5 \\
\hline 4. & Pengendalian diri dan interaksi & 4 & 3 \\
\hline 5. & Menghormati orang lain dan diri sendiri & 5 & 4 \\
\hline 6. & $\begin{array}{l}\text { Kemampuan dalam mengungkapkan perasaan setelah } \\
\text { melakukan yoga }\end{array}$ & 4 & 3 \\
\hline 7. & Menunjukkan kemandirian & 5 & 5 \\
\hline 8. & $\begin{array}{l}\text { Memotivasi diri sendiri dan orang lain untuk mengikuti } \\
\text { yoga dengan baik. }\end{array}$ & 4 & 4 \\
\hline
\end{tabular}

Keterangan : (1) = sangat kurang; (2) = kurang; (3) = cukup; (4) = baik; (5) = sangat baik 
Post test diberikan untuk mengetahui peningkatan pengelolaan kecerdasan emosi melalui yoga. Post test untuk peserta didik diberikan dalam bentuk permainan. Sedangkan untuk guru diberikan post test dalam bentuk pertanyaan dan dijawab secara lisan.

\subsection{Pembahasan}

Perkembangan kecerdasan emosi semakin perlu dipahami, dimiliki, dan diperhatikan mengingat kondisi kehidupan pada saat ini semakin kompleks dan memberikan dampak yang sangat buruk terhadap perkembangan kehidupan emosi anak. Hasil survey terhadap para orang tua dan guru menunjukkan adanya kecenderungan yang sama diseluruh dunia yaitu generasi sekarang lebih banyak memiliki kesulitan emosi dari pada generasi sebelumnya. Generasi sekarang lebihkesepian dan pemurung, lebih beringasan, kurang memiliki sopan santun, mudah cemas, gugup serta lebih impulsive (tanpa berpikir panjang dalam bertindak) (Djawad Dahlan,2000).

Berbagai strategi untuk mengembangkan kecerdasan emosi yang merupakan aspek penting dalampenentuan kesuksesan seseorang dimasa depan sudah dilaksanakan seperti ceramah dan pelatihan tentang pengenalan dan pengendalian emosi dimana para guru dan peserta didik mendapatkan pengetahuan tentang apa emosi itu dan bagaimana cara mengembangkannya. Namun, strategi tersebut ternyata belummemberikan perubahan terutama perubahan dalam meningkatkan kemampuan mereka dalam mengelola emosi mereka. Padahal sebagai seorang guru, kecerdasan emosional sangat penting, terutama sekali untuk memberikan perubahan pula bagi peserta didik dalam mengembangkan kecerdasan emosi mereka, karena guru dan peserta didik memiliki hubungan yangerat.

Hal tersebut di atas ternyata benar karena hasil pre test guru dan peserta didik yang dilaksanakan pada kegiatan penelitian ini menunjukkan $85 \%$ guru mengatakan emosi itu adalah rasa marah atau sedih, $97 \%$ dari $85 \%$ mengatakan sering tidak menyadari emosi yang timbul dari diri mereka. $100 \%$ peserta pernah merasakan emosi negative yang meledak ledak, $80 \%$ peserta mengatakan bahwa emosi negative tersebut dapat memberikan dampak yang fatal seperti stress, $20 \%$ peserta mengatakan emosi negative tersebut dapat diredam tapi sangat susah dan memerlukan waktu, $95 \%$ peserta belum pernah melakukan yoga sebagai salah satu cara untuk mengelola emosi, $5 \%$ pernah mengikuti yoga namun sangat jarang mempraktekkannya. Sedangkan pada anak 96\%belum mampu mengendalikan dan mengelola emosiuntuk dapat bertahan menunggu agar mendapatkan tambahan permen lagi.

Dari permasalahan tersebut selanjutnya dilaksanakan kegiatan peningkatan kecerdasan dalam mengelola emosi dengan menggunakan yoga. Aktivitas meditasidapat melatih seseorang untuk merasakan perasaan yang sedang dirasakan, mengeluarkan emosi yang dipendam sehingga mendapatkan ketenangan dan kenyamanan, dan meningkatkan produktifitas pembelajaran dikelas. Rachmawati (1998) mengatakan bahwa proses relaksasi dapat dilakukan pada anak cukup efektif untuk pengenalan emosi diri mereka sendiri atau terbentuknya keterampilan emotional awareness. Dari hasil penelitian bahwa kegiatan yoga inisangat membantu guru dan peserta didik dalam mengenali dan mengelola emosi mereka. Dimana emosi merupakan factor penting sebagai penentu kesuksesan dimasa depan. 
Mengingat permasalaham utama dari guru dan peserta didik adalah rendahnya kemampuan mereka dalam mengenali bentuk bentuk emosi dalam diri, perlu dilakukan kegiatan pelatihan yoga yang sudah terbukti mampu meningkatkan kemampuan guru dan peserta didik dalam mengelolaemosi.

Dalam pelaksanaan pelatihan juga dilaksanakan observasi yang menunjukkan bahwa ketekunan mendengarkan informasi dari peserta atas materi yang disampaikan pada kategori 5 (sangat baik) untuk guru dan 3(cukup) untuk peserta didik. Keseriusan dalam melakukan gerakan yoga dalam mengikuti pelatihan menunjukkan angka 5 (sangat baik) untuk guru dan 4 (baik) untuk peserta didik. Keseriusan dalam melakukan aktivitas meditasi menunjukkan angka 5 (sangat baik ) untuk guru dan 5 (sangat baik) untuk peserta didik. Hal ini ditunjukkan dengan sikap yang sangat positif saat mengikuti meditasi dengan sangat khusuk. Pengendalian diri dan mengungkapkan perasaan menunjukkan angka 4(baik) untuk guru dan 3 (cukup ) untuk peserta didik, hal ini ditunjukkan dengan kemampuan dalam memusatkan perhatian saat kegiatan yoga berlangsung. Kemampuan untuk memotivasi diri sendiri dan orang lain menunjukkan angka 4 (baik) untuk guru dan 4 (baik) untuk peserta didik. Hal ini ditunjukkan dengan sikap pantang menyerah dan saling membantu saat melakukan gerakan yoga dan meditasi. Mereka diberikan pelatihan untuk merasakan emosi yang ada di dalam diri, dan bagaimana cara mengelola emosi tersebut. Penelitian ini dilakukan untuk mencari jawaban apakah kecerdasan emosional dapat dikembangkan dengan cara kegiatan yoga.

Hasil dari keseriusan mereka dapat dilihat setelah dilakukan post test untuk guru dan peserta didik sebagai berikut :
1. Dalam mengenali emosi diri sendiri, kemampuan rata rata guru adalah 90 , sedangkan rata rata peserta didik 75. Hasil ini merupakan hasil yang sangat baik sebagai awal untuk memahami diri sendiri.

2. Dalam mengelola dan mengendalikan emosi, kemampuan rata rata guru adalah 82 dan peserta didik 80 . Hal ini terlihat bagaimana guru dan peserta didik mampu dapat bersabar dan bertahan saat melakukan meditasi.

3. Dalam memanfaatkan emosi secara produktif, kemampuan rata rata guru adalah 78 dan peserta didik 73. Disini kemampuan rata rata guru paling rendah karena kurangnya pertimbangan yang matang saat akan melakukan sesuatu

4. Dalam membangun rasa empati kemampuan rata rata guru adalah 81 sedangkan peserta didik 65. Kemampuan peserta didik dalam mengembangkan rasa empati paling rendah dan memerlukan pembiasaan dalam sehariharinya

5. Dalam membina hubungan dengan orang lain, kemampuanrata rata guru dan peserta didik adalah 90. Ini merupakan hasil yang luar biasa, mereka sudah mampu bersosiallisasi dan menyesuaikan diri dengan lingkungannya.

\section{SIMPULAN DAN SARAN}

\subsection{Simpulan}

Berdasarkan hasil kegiatan dapat disimpulkan bahwa:

a. Pelatihan pengelolaan kecerdasan emosional melalui kegiatan yoga dapat meningkatkan kemampuan guru dan peserta didik dalam mengenal bentuk bentuk emosi diri sendiri.

b. Pelatihan pengelolaan kecerdasan emosional melalui kegiatan yoga dapat meningkatkan kemampuan guru dan 
peserta didik dalammengelola emosi dalam diri.

c. Pelatihan pengelolaan kecerdasan emosional melalui kegiatan yoga dapat meningkatkan kemampuan guru dan peserta didik dalammembina hubungan dan berkomunikasi dengan orang lain.

\subsection{Saran}

Dalam pelaksanaan pelatihan ini diusulkan beberapan saran oleh peneliti untuk selanjutnya yaitu:

a. Untuk guru disarankan untuk lebih aktif dan antusias dalam mengembangkan salah satu kemampuan diri yaitu kecerdasan emosional yang mana hal itu sangat penting bukan hanya untuk kesuksesan diri sendiri tapi kesuksesan untuk memberikan lingkungan yang terbaik untuk anak anak dalam mengembangkan kecerdasan emosionalnya dengan kegiatanyoga.

b. Untuk peserta didik disarankan untuk lebih aktif dan kreatif dalam mengikuti kegiatan yoga karena yoga dapat memberikan manfaat yang sangat luar biasa selain untuk perkembangan kecerdasan emosional, juga untuk perkembangan fisik, mental, dan spiritual.

\section{Daftar Pustaka}

Aisyah, Siti. 2015. Perkembangan Peserta Didik dan Bimbingan Belajar. Yogyakarta: Deepublish.

Dahlan, Djawad. 2000. Psikologi Perkembangan Anak \& Remaja, Penerbit Rosda Karya.

Goleman, D. 1995. Emotional Intelligent. Jakarta: Gramedia PustakaUtama.

Goleman, Daniel 1999. Kecerdasan Emosi Untuk Mencapai Puncak Prestasi. Jakarta: Gramedia Pustaka Utama.

Hildayani, Rini, Dkk. 2011. Psikologi Perkembangan Anak. Jakarta: Universitas Terbuka.

Mariyana, Rita;Ali Nugraha; Yeni Rachmawati. 2010. Pengelolaan Lingkungan Belajar. Jakarta: Kencana Prenada Media Group.

Nugraha, Ali dan Rahmawati. 1998. Terapi Musik Sebagai Bimbingan Konseling dalam Mereduksi Stress Anak Sekolah Dasar. Skripsi. Bandung: IKIP Bandung. Sindhu, Pujiatuti. 2013. Panduan Lengkap Yoga: Untuk Hidup Sehat dan Seimbang. Bandung. PT. Mizan Pustaka. 